\title{
UURNAL KEEUANGANDANBISNIS
}

\section{Vol. 16, No. 1, Maret 2018}

AnalisisPengaruh Kecerdasan Intelektual Terhadap Kemampuan Akuntansi Dengan Kecerdasan Emosional Dan Spiritual Sebagai Pemoderasi Ria Manurung

Perbedaan Persepsi Mahasiswa Program Studi Akuntansi dan Manajemen Terhadap Kualitas Layanan Jasa Pendidikan di Universitas Katolik Musi Charitas Palembang Maria Josephine Tyra dan Andreas Sarjono

Pengaruh Kualitas Produk dan Kualitas Pelayanan Terhadap Kepuasan Pelanggan Mobile Broadband di Kota Palembang Hendrianto, Diah Natalisa, dan Dian Eka

Analisis Pengaruh Diversitas Gender, Kepemilikan Institusional, dan Ukuran Perusahaan Terhadap Kinerja Keuangan

Lisaime dan Dewi Sri

Demografi Terhadap Pengambilan Keputusan Investasi

(Studi Kasus Pegawai Kantor Badan Kepegawaian Daerah Sumatera Selatan) Nyimas Artina dan Idham Cholid

Pengaruh Profitabilitas, Opini Auditor, dan Ukuran Perusahaan Terhadap Ketepatan Waktu Penyampaian Laporan Keuangan di Bursa Efek Indonesia Periode Tahun 2012-2014

Hefi Dwi Oktavia dan Diah Hari Sur yaningrum

Pengaruh Strategi Prospector dan Defender, Kompensasi Eksekutif dan Ukuran Perusahaan Terhadap Nilai Perusahaan

Ratih Yuni Lestari, Brigita Dilla Savirach, Oktavia, dan Novita Febriany 


\section{Anticles}

Analisis Pengaruh Kecerdiasan Intelektual Terhadap Kemampuan Akunbansi dengan Kecerdasan Emasional dan spìritual sebagai pemoderasi

Fia Manurung

Tư pof

Perbedaan Persepsi Mahasiswa Program Studi Akuntansi dan Manajemen Terhadap Kualitas Layanan jasa Pencidikan Di Universitas Katolik Musl Charitas palembang

Maria Josephine Tyra, Andreas Sarjono

Ba poff

Pengaruh Kualitas Produk dan Kualltas Pelayanan Terhadap Kepuasen Pelanggan Mobile Broadband Di Kota Palembang

Hencilanto Handrianto, Diah Natalisa, Dian Eka

aㅣㄹ poff

Analisis Pengaruh Diversitas Gender, Kepemilikan Institusional, dan Ukuran Perusahaan terhadap Kinerja Keuangan

Dewi Sri, Lisaime.

궁 poof

Pengaruh Tingkat Literasi Keuangan dan Faktor Demograñ Terhadap Pengambilan Keputusan investasi (studi) Kasus Pegawai Kantor Baden Kepegawaian Daerah Sumatera Seiatan)

Nyimas Artina, Idham cholid

\section{[e pof}

Pengaruh Prontabilitas, Opini Auditor, dan Ukuran Perusahaan Terhadiap Ketapatan Waktu Penyampaian Laporan Keuangas di Bursa tefek lndonesia Periode Tahun 2012-2014

Hefi Dwi Oktavia, Diah Hari Suryaningrum

$$
\text { D POF }
$$

Pengaruh Strategi Prospectof dan Defender, Kompensasi Eksekutif, Ukuran Perusahaan Terhadap Nulal Perusahaan

Rath Yuni Lestari, Brigita Dilla Savirach, Oktavia , Novita Febriany 


\title{
ANALISIS PENGARUH DIVERSITAS GENDER, KEPEMILIKAN INSTITUSIONAL, DAN UKURAN PERUSAHAAN TERHADAP KINERJA KEUANGAN
}

\author{
LISAIME $^{7}$
}

DEWI SRI ${ }^{8}$

dewi_sri@ukmc.ac.id

\begin{abstract}
Research on the analysis of the effect of gender diversity, institutional ownership, and firm size on financial performance using the population of manufacturing companies listed on the Indonesia Stock Exchange (IDX). Sampling was done by purposive sampling method as many as 65 companies. This study wants to see the effect of gender diversity, institutional ownership, and firm size on financial performance. Based on the results of testing the hypothesis obtained that $\mathrm{Ha}$ is accepted, namely institutional ownership has a positive effect on financial performance. While the hypothesis for the gender of the board of directors, the gender of the board of directors and the size of the company shows that HO is accepted, namely the gender of the board of directors, the gender of the board of directors, and the size of the company does not have a positive effect on financial performance
\end{abstract}

Keywords: gender, commissioners, board of directors, institutional ownership, firm size, $R O A$.

\begin{abstract}
ABSTRAKSI
Penelitian mengenai analisis pengaruh diversitas gender, kepemilikan institusional, dan ukuran perusahaan terhadap kinerja keuangan menggunakan populasi perusahaan manufaktur emiten di Bursa Efek Indonesia (BEI). Pengambilan sampel dilakukan dengan metode purposive sampling sebanyak 65 perusahaan. Penelitian ini ingin melihat pengaruh diversitas gender, kepemilikan institusional, dan ukuran perusahaan terhadap kinerja keuangan. Berdasarkan hasil pengujian hipotesis diperoleh bahwa $\mathrm{H}_{\mathrm{a}}$ diterima, yaitu kepemilikan institusional berpengaruh positif terhadap kinerja keuangan. Sedangkan hipotesis untuk gender dewan komisaris, gender dewan direksi dan ukuran perusahaan menunjukkan bahwa $\mathrm{H}_{0}$ diterima, yaitu gender dewan komisaris, gender dewan direksi, dan ukuran perusahaan tidak berpengaruh positif terhadap kinerja keuangan.
\end{abstract}

\footnotetext{
${ }^{7}$ Lisaime adalah alumni mahasiswa/i Program Studi Akuntansi Universitas Katolik Musi Charitas Palembang

${ }^{8}$ Dewi Sri adalah dosen tetap Program Studi Akuntansi Universitas Katolik Musi Charitas

Palembang
} 


\section{Kata kunci: gender, dewan komisaris, dewan direksi, kepemilikan institusional, ukuran perusahaan, ROA}

\section{PENDAHULUAN}

Perusahaan merupakan suatu bentuk organisasi yang dibentuk oleh beberapa orang yang di dalamnya terdapat pengelola perusahaan yang bertujuan untuk menghasilkan laba dari apa yang dikerjaan selama periode berjalan. Keberhasilan dalam mencapai tujuan perusahaan merupakan prestasi manajemen. Kinerja perusahaan merupakan suatu gambaran tentang kondisi keuangan perusahaan yang dianalisis dengan alat-alat analisis keuangan, sehingga dapat diketahui mengenai baik buruknya keadaan keuangan suatu perusahaan yang mencerminkan prestasi kerja dalam periode tertentu. Hal ini sangat penting agar sumber daya digunakan secara optimal dalam menghadapi perubahan lingkungan.

Kinerja dari manajemen dalam sebuah perusahaan perlu dilakukan penilaian. Penilaian kinerja keuangan merupakan salah satu cara yang dapat dilakukan oleh pihak manajemen agar dapat memenuhi kewajibannya terhadap investor dan juga untuk mencapai tujuan yang telah ditetapkan oleh perusahaan.Selain itu, kinerja keuangan juga dapat digunakan untuk melihat keberhasilan perusahaan menghasilkan laba.

Setiap tahun, perusahaan yang go public menerbitkan laporan tahunannya. Laporan ini berisi data keuangan maupun non keuangan yang bertujuan memberikan informasi bagi para penggunanya dan dapat digunakan untuk menganalisis kondisi perusahaan. Laporan keuangan merupakan alat yang sangat penting untuk memperoleh informasi sehubungan dengan posisi keuangan dan hasil-hasil yang telah dicapai oleh perusahaan. Dengan melihat laporan keuangan suatu perusahaan akan tergambar di dalamnya aktivitas perusahaan tersebut. Oleh karena itu, laporan keuangan perusahaan dapat digunakan sebagai alat untuk komunikasi dan juga digunakan sebagai alat pengukur kinerja keuangan perusahaan tersebut.

Di dalam sebuah perusahaan pasti memiliki manajemen yang bertugas untuk melakukan aktivitas perusahaannya yang bertujuan untuk meningkatkan kinerja keuangan perusahaan. Manajemen perusahaan dapat terdiri dari dewan komisaris dan dewan direksi yang merupakan komponen utama dalam menjalankan perusahaan. Dalam perusahaan, dewan direksi memiliki tanggung jawab membuat keputusan-keputusan yang akan mempengaruhi arah kebijakan perusahaan. Direktur atau dewan komisaris perusahaan adalah orang yang mempunyai keahlian dan pengetahuan tentang operasional perusahaan dan mengetahui dengan pasti apa yang terjadi di dalam perusahaan (Bhagat and Black, 1999 dalam Sudiartana, 2013). Tidak ada dewan komisaris dan dewan direksi yang memimpin perusahaan, secara otomatis aktivitas perusahaan tidak berjalan dengan baik, karena pengelola perusahaan tidak ada.

Salah satu isu penting yang berkaitan dengan struktur beserta fungsi dewan komisaris dan direksi adalah adanya diversitas anggota dewan komisaris dan direksi. Diversitas dewan komisaris dan direksi menggambarkan distribusi perbedaan antara anggota dewan yang berkaitan dengan karakteristik-karakteristik mengenai perbedaan sikap dan opini (Ararat et al., 2010 dalam Basundari dan I 
Komang, 2013). Lucterath-Rovers (2010) dalam Basun dari dan I Komang (2013) menjelaskan keberadaan wanita dalam jajaran dewan komisaris dan direksi menandakan bahwa perusahaan memberikan kesempatan yang sama bagi setiap orang (tidak diskriminasi), memiliki pemahaman yang luas mengenai pasar dan konsumen perusahaan, sehingga pada akhirnya akan meningkatkan reputasi (legitimasi) dan nilai perusahaan.

Istilah gender digunakan dalam konteks sosial untuk menjelaskan karakteristik antara pria dan wanita maupun sifat-sifat feminin dan maskulin dalam masyarakat. Fenomena keberagaman gender telah banyak ditemukan di perusahaan Indonesia maupun perusahaan negara asing lainnya. Sudut pandang yang positif mengenai wanita yang berkompeten layak mendapatkan kesempatan memimpin, melayani, dan mengelola perusahaan dengan baik (Carter, et al 2010). Dengan adanya diversitasgender di suatu perusahaan dapat menguntungkan perusahaan. Perbedaan pendapat serta informasi yang diperoleh dari masingmasing anggota dewan akan membangun suatu pondasi yang kuat untuk bersaing dengan perusahaan pesaing.

Dibeberapa negara telah menerbitkan peraturan mengenai keterlibatan wanita dalam dewan komisaris dan dewan direksi. Misalnya Norwegia memiliki hukum yang mengharuskan $40 \%$ dari dewan direksi dan komisaris dalam suatu perusahaan adalah wanita (Rose, 2007 dalam Carter, et al. 2010). Selain Norwegia, Spayol juga baru mengesahkan undang-undang yang mengharuskan keterlibatan wanita dalam dewan direksi dan komisaris (Adam \& Ferreira, 2009 dalam Carter, et al. 2010). Dalam upaya meningkatkan peran wanita di lingkup dewan komisaris dan direksi untuk meningkatkan kinerja keuangan perusahaan, beberapa negara telah menerapkan hal tersebut. Di Indonesia, berdasarkan hasil studi Centre for Governance, Institutions and Organisations (CGIO) National Singapore Univercity Business School (2012), persentase wanita pada dewan komisaris dan dewan direksi perusahaan publik yang terdaftar di Indonesia Stock Exchange (IDX) sebesar 11,6\%. Dari nilai tersebut, sebesar 34\% dewan perusahaan hanya memiliki satu wanita pada anggota dewan dan hanya $2,8 \%$ yang memiliki empat atau lebih peran wanita dalam anggota dewan. Perusahaanperusahaan terbaik memiliki lima atau lebih anggota dewan wanita diantaranya Tempo Scan Pacific Tbk, Bank CIMB Niaga Tbk, Bank Internasional Indonesia Tbk, Ciputra Surya Tbk, dan Mitra Adiperkasa Tbk (Tempo.com diakses pada tanggal 10 Maret 2016).

Dan sampel pada penelitian ini (65 sampel perusahaan manufaktur), jumlah wanita dalam anggota dewan komisaris pada tahun 2014 adalah 22 orang (sekitar 33\% dari jumlah sampel) dan pada tahun 2015 meningkat berjumlah 23 orang (sekitar 35\% dari jumlah sampel). Meningkatnya jumlah wanita pada tahun 2015 dikarenakan salah satu anggota dewan komisaris PT Astra Internasional, Tbk meninggal dunia sehingga anggota dewan komisaris kosong dan harus di ganti dengan anggota baru. Jumlah wanita dalam dewan direksi pada sampel penelitian ini di tahun 2014 berjumlah 23 orang (sekitar 35\% dari jumlah sampel) dan meningkat pada tahun 2015 menjadi 25 orang (sekitar 38\% dari jumlah sampel). Meningkatnya jumlah wanita menjadi anggota dewan direksi terjadi pada PT Budi Statch \& Sweetener, Tbk dan PT Gudang Garam, Tbk. Hal ini 
dikarenakan pengangkatan sesuai dengan RUPS (Rapat Umum Pemegang Saham) pada perusahaan tersebut.

Pandangan tentang wanita yang tidak dapat memimpin suatu perusahaan sebaiknya dihilangkan.Banyak opini tentang wanita yang tidak dapat memajukan perusahaan. Misalnya saja ketika suatu perusahaan yang dipimpin oleh wanita tidak dapat menghasilkan laba akan dianggap wanita tidak memiliki kemampuan akan menghasilkan laba. Ada juga yang berpendapat bahwa seorang wanita dapat menjadi anggota dewan karena bantuan dari kerabat maupun keluarga yang juga menjadi salah satu orang penting dalam memajukan perusahaan. Walaupun di era globalisasi seperti ini masih ada saja pandangan wanita tidak bisa bekerja di perusahaan melainkan wanita harus mengurus rumah tangga dan mengurus anakanak di rumah.

Kinerja perusahaan merupakan hasil akhir dari proses kinerja manajemen dalam suatu periode ke periode lainnya. Penilaian terhadap kinerja diperlukan untuk melihat kemampuan perusahaan menghasilkan laba, mengalokasikan, dan mengelola sumber dayanya.Salah satu faktor yang dapat mempengaruhi kinerja perusahaan adalah struktur kepemilikan institusional. Kepemilikan institusional merupakan kepemilikan saham perusahaan terbesar dimiliki oleh institusi atau lembaga (perusahaan asuransi, bank, perusahaan investasi, asset management dan kepemilikan institusi lain). Kepemilikan institusional memiliki kemampuan untuk mengendalikan pihak manajemen melalui proses monitoring secara efektif dan dapat meningkatkan kinerja keuangan perusahaan. Karena tingkat pengawasan dari investor institusional sangat tinggi, pihak manajemen dituntut untuk memberikan hasil yang terbaik bagi perusahaan serta investor.Sehingga dari kedua belah pihak antara manajemen dan investor tidak dirugikan.

Tujuan utama didirikannya perusahaan adalah untuk meningkatkan kesejahteraan pemegang saham.Kesejehteraan dapat ditingkatkan melalui kinerja keuangan perusahaan yang baik.Tujuan kedua didirikannya perusahaan adalah untuk kesejahteraan pihak-pihak seperti konsumen, komunitas, karyawan, dan kreditur.Tujuan kedua adalah penggerak bagi tercapainya tujuan utama (Atkinson, Banker, Kaplan, and Young 1997 dalam Fachrudin, 2011).

Selain diversitas gender dewan komisaris dan dewan direksi serta kepemilikan institusional yang dapat mempengaruhi kinerja keuangan perusahaan, kinerja keuangan perusahaan juga dapat dipengaruhi oleh ukuran perusahaan. Besar kecilnya perusahaan yang diukur dengan total asset yang dimiliki berpengaruh terhadap kinerja keuangan perusahaan tersebut. Secara umum perusahaan yang memiliki total aset yang relatif besar dapat melakukan aktivitas dan beroperasi menghasilkan laba yang lebih tinggi dibandingkan dengan perusahaan yang mempunyai total aset lebih rendah. Kinerja keuangan yang baik merupakan prestasi dari kerja perusahaan.

Lin (2006) serta Wright et al. (2009) dalam Isbanah (2015) menemukan bahwa ukuran perusahaan berpengaruh positif terhadap kinerja keuangan.Jadi, semakin besar ukuran perusahaan, semakin bagus pula kinerja keuangan perusahaan tersebut.Kinerja perusahaan memperlihatkan kemampuan perusahaan untuk memberikan keuntungan dari aset, ekuitas, maupun hutang. Ukuran perusahaan dianggap mampu mempengaruhi kinerja perusahaan karena 
perusahaan yang besar dapat menurunkan agency cost. Perusahaan dengan aset yang besar dan dapat menghasilkan laba berarti perusahaan tersebutdapat memanfaatkan total aset yang dimilikinya semaksimal mungkin untuk menghasilkan laba sehingga dapat meningkatkan kinerja keuangan perusahaan.

Semakin baik informasi yang diberikan oleh pihak manajemen perusahaan kepada pihak luar perusahaan, semakin besar pula peluang perusahaan mendapatkan modal tambahan untuk meningkatkan perusahaan.Semakin tinggi modal yang disetor oleh investor semakin baik pula kinerja keuangan perusahaan tersebut. Karena pihak manajemen akan memberikan yang terbaik dan bekerja semaksimal mungkin bagi perusahaan dan investor yang telah menamamkan modalnya ke perusahaan terebut.

Penelitian yang dilakukan oleh Theacini dan I Gede (2014) serta Sari dan Bahtiar (2014) menemukan bahwa adanya pengaruh yang signifikan ukuran perusahaan terhadap kinerja keuangan perusahaan. Total aset yang besar menunjukkan kemampuan perusahaan untuk menghasilkan keuntungan yang lebih besar dengan mengelola aset yang tersedia dengan bijak dan perencanaan yang matang, sehingga perusahaan akan memperoleh keuntungan yang besar pula.Berbeda dengan hasil penelitian yang dilakukan oleh Mahaputeri dan I.Kt.Yadnyana (2014) dan Isbanah (2015) yang menemukan bahwa ukuran perusahaan berpengaruh negatif terhadap kinerja keuangan perusahaan.Semakin besar ukuran perusahaan belum tentu kinerja keuangannya juga bagus.Hal ini dapat disebabkan ukuran perusahaan yang besar tersebut belum didukung pengelolaan yang bagus.

Beberapa penelitian mengenai pengaruh struktur kepemilikan institusional terhadap kinerja keuangan perusahaan telah dilakukan.Hasil penelitian yang dilakukan oleh Fauzan, Nadirsyah, dan Muhammad (2012) dan Waskito (2014) menunjukkan bahwa kepemilikan institusional berpengaruh positif terhadap hubungan kinerja keuangan perusahaan dan nilai perusahaan.Penelitian ini berlawanan dengan penelitian yang dilakukan oleh Wehdawati, Fifi, dan Sufi (2015) yang menunjukkan bahwa struktur kepemilikian institusional tidak berpengaruh terhadap kinerja keuangan perusahaan.

Penelitian mengenai pengaruh keberagaman gender terhadap kinerja keuangan perusahaan juga ada beberapa penelitian yang telah dilakukan. Penelitian yang dilakukan oleh Hanani dan Y. Anni (2011) menunjukkan bahwa tidak ada pengaruh positif keberagaman gender dewan komisaris dan dewan direksi terhadap kinerja keuangan. Berbeda dengan hasil penelitian yang lakukan oleh Ramadhani dan Desi (2015) menunjukkan bahwa terdapat pengaruh positif diversitas gender terhadap kinerja keuangan. Penelitian yang dilakukan oleh Carter, et al (2010) juga menemukan hubungan positif diversitas gender terhadap kinerja keuangan.

Berdasarkan latar belakang dan penelitian terdahulu maka penulis akan melakukan penelitian tentang pengaruh diversitas gender dewan komisaris dan dewan direksi, kepemilikan institusional, dan ukuran perusahaan terhadap kinerja keuangan.

Berdasarkan latar belakang yang telah diuraikan diatas, adapun masalahmasalah yang akan diajukan dalam penelitian ini adalah sebagai berikut: 
1. Apakah terdapat pengaruh positif diversitas gender dewan komisaris terhadap kinerja keuangan perusahaan?

2. Apakah terdapat pengaruh positif diversitas gender dewan direksi terhadap kinerja keuangan perusahaan?

3. Apakah terdapat pengaruh positif struktur kepemilikan terhadap kinerja keuangan perusahaan?

4. Apakah terdapat pengaruh positif ukuran perusahaan terhadap kinerja keuangan perusahaan?

\section{TELAAH TEORITIS DAN PENGEMBANGAN HIPOTESIS \\ Teori Keagenan (Agency Theory)}

Teori keagenan menekankan pentingnya pemilik perusahaan (pemegang saham) menyerahkan pengelolaan perusahaan kepada tenaga-tenaga profesional (agents) yang lebih mengerti dalam menjalankan bisnis sehari-hari. Tujuan dipisahkannya pengelolaan dari kepemilikan perusahaan agar pemilik perusahaan mendapatkan keuntungan yang maksimal dengan biaya yang efisien (Sutedi, 2011:13).Secara kontras, adanya kontrol dari pemegang saham terhadap perusahaan dapat membuat pelaksanaan kontrol terhadap pihak manajemen menjadi lebih mudah dan juga dapat menurunkan potensi konflik kepentingan yang timbul (Surya dan Ivan, 2008:4). Adanya kepemilikan institusional dapat digunakan untuk mengurangi agency cost (biaya keagenan) yang akan timbul.Dengan kepemilikan yang besar (lebih dari 5\%), kemampuan investor institusional memonitor manajemen perusahaan lebih besar.Semakin tinggi tingkat kepemilikan institusional semakin tinggi pula tingkat pengawasan terhadap manajemen.

\section{Teori Ketergantungan Sumber Daya}

Teori memiliki dua pandangan yang menunjukan hubungan keberagaman gender dan kinerja. Pandangan pertama adalah hubungan lingkungan (environmental linkage perspective). Dalam teori ini manajer merupakan bagian organisasi dan lingkungannya, dengan menyediakan informasi dan sumber daya bagi organisasi, manajer akan melindungi organisasi dari ketidakpastian lingkungan. Berdasarkan pandangan ini, secara individual manajer dengan latar belakang yang berbeda-beda akan menyediakan sumber daya penting bagi organisasi.

Teori ketergantungan sumber daya mempunyai dasar untuk diversitas gender dewan komisaris dan dewan direksi. Menurut Hillman et al. (2000) dalam Carter et al. (2010) dalam teori ketergantungan sumber daya, keragaman gender dewan komisaris maupun dewan direksi akan memberikan keuntungan yang berbeda bagi perusahaan. Gender dewan komisaris maupun dewan direksi yang berbeda akan menyediakan sumber daya manusia yang berkualitas, sehingga dapat menghasilkan kinerja yang baik pula bagi perusahaan. Keanekaragaman gender memiliki potensi untuk mengingkatkan informasi yang diberikan oleh dewan kepada manajer perusahaan karena informasi yang diberikan unik dari dewan yang beragam yang akan lebih mampu menghadapi tantangan dan dinamika lingkungan bisnis (Noviwijaya dan Abdul, 2013). 


\section{Teori Signalling}

Signalling theory menekankan kepada pentingnya informasi yang dikeluarkan oleh perusahaan terhadap kebutuhan investasi pihak di luar perusahaan. Informasi merupakan unsur penting bagi investor dan pelaku bisnis karena informasi pada hakekatnya menyajikan keterangan, catatan atau gambaran baik untuk keadaan masa lalu, saat ini maupun keadaan masa yang akan datang bagi kelangsungan hidup suatu perusahaan dan bagaimana pasaran efeknya. Informasi yang lengkap, relevan, akurat, dan tepat waktu sangat diperlukan oleh investor di pasar modal sebagai alat analisis untuk mengambil keputusan investasi.

\section{Kinerja Keuangan Perusahaan}

Kinerja perusahaan merupakan indikator dari baik buruknya keputusan manajemen dalam pengambilan keputusan. Manajemen dapat berinteraksi dengan lingkungan interen maupun eksteren melalui informasi.Informasi yang dibutuhkan oleh beberapa pihak dituangkan dalam laporan keuangan perusahaan. ROA adalah rasio keuangan perusahaan yang berhubungan dengan profitabilitas mengukur kemampuan perusahaan menghasilkan laba pada tingkat pendapatan, aset, dan modal saham tertentu. Semakin tinggi laba yang dihasilkan suatu perusahaan semakin baik pula kinerja keuangan perusahaan tersebut. Dengan kata lain, semakin tinggi rasio ROA maka semakin baik produktivitas asset dalam memperoleh keuntungan bersih. Hal ini selanjutnya akan meningkatkan daya tarik perusahaan kepada investor. Para investor akan berniat menanamkan modalnya yang dapat menghasilkan laba yang tinggi. Karena laba yang tinggi akan menguntungkan investor pula.

\section{Diversitas Gender Dewan Komisaris}

Dalam sebuah perusahaan pasti memiliki dua dewan yaitu dewan komisaris dan dewan direksi.Dewan direksi bertugas menjalankan operasi perusahaan dan dewan komisaris berwenang untuk mengawasi hasil kerja dari dewan direksi (Pudjiastuti dan Mardiyah, 2007 dalam Hanani dan Y Anni, 2011).Di Indonesia, menurut Undang-Undang Perseroan Terbatas, menyatakan bahwa baik dewan komisaris dan dewan direksi yang dipilih harus memberikan pertanggungjawaban dalam RUPS (Rapat Umum Pemegang Saham).Sedangkan di negara-negara lain hanya dewan komisaris yang disebut supervisory board dipilih dan harus memberi pertanggungjawaban dalam RUPS (Rapat Umum Pemegang Saham).

Manajemen perusahaan harus memiliki komposisi yang tepat sehingga dapat menghasilkan keputusan yang tepat untuk memajukan perusahaan. Keberhasilan organisasi sangat ditentukan oleh pimpinan organisasinya. Terdapat perbedaan gaya kepemimpian antara wanita dan pria.Wanita sebagai dewan komisaris diharapkan dapat mendorong informasi mengenai perusahaan diungkapkan lebih transparan kepada pihak yang berkepentingan. Wanita sebagai dewan komisaris dapat memberikan dukungan, memotivasi, dan cenderung mendengarkan para karyawannya dibandingkan dengan laki-laki. Dengan gaya 
kepemimpinan wanita dalam dewan komisaris dapat meningkatkan kinerja keuangan perusahaan. Sehingga banyak investor yang tertarik dalam menanamkan modalnya di perusahaan tersebut.

Dari data statistik Departemen Tenaga Kerja dan Transmigrasi, 13\% perempuan dari total penduduk bekerja sebagai tenaga kepemimpinan. Dengan adanya peran wanita dalam dewan komisaris akan membantu pengambilan keputusan yang tepat dengan resiko yang lebih rendah. Menurut penelitian Carter (2002) dalam Hanani dan Y Anni (2011), perusahaan yang memiliki 2 atau lebih wanita dalam dewan akan memiliki kinerja perusahaan yang tinggi daripada perusahaan yang kurang dari 2 atau tidak memiliki peran wanita dalam jajaran dewan komisaris. Dalam penelitian yang dilakukan oleh Carter, et al (2010) menyatakan bahwa tidak ada hubungan negatif antara diversitas gender dewan komisaris dengan kinerja keuangan. Hasil yang sama pada penelitian yang dilakukan oleh Francoeur, et al (2008).

\section{Diversitas Gender Dewan Direksi}

Banyak perusahaan sangat memperhatikan dewan direksi sebagai sesuatu hal yang penting, karena tugas dari dewan direksi adalah menjalankan semua kegiatan perusahaan yang telah dibuat oleh CEO . Di Amerika, 14,8\% dari 500 perusahaan yang terdaftar, dewan direksinya adalah wanita (Catalyst, 2007 dalam Hanani dan Y Anni, 2011). Persentase dewan direksi di Australia adalah 8,7\%, Kanada 10,6\%, Jepang 0,4\% dan Eropa 8,0\% (Hanani dan Y Anni, 2011). Peran wanita dalam jajaran dewan direksi telah banyak diterapkan di beberapa negara karena tekanan untuk memilih wanita menjadi anggota dewan direksi.Hal ini

menjadi suatu keunggulan kompetitif (Watson, et al. 1993 dalam Kartikarini dan Siti dikarenakan kemampuan wanita dalam memimpin perusahaan cukup baik.

Diversitas dewan direksi mengarah pada pengetahuan, kreativitas, dan inovasi yang selanjutnya, 2012). Selain itu, diversitas dewan direksi dapat memperbanyak pendapat-pendapat yang baik dalam pengambilan keputusan untuk meningkatkan kinerja keuangan perusahaan. Dewan direksi wanita merupakan bagian diversitas gender yang paling berpengaruh terhadap kinerja keuangan perusahaan. Karena dewan direksi juga mempunyai tugas terlibat langsung dapat penyusunan laporan keuangan, maka secara tidak langsung peran wanita dalam dewan direksi dapat mempengaruhi kinerja keuangan perusahaan.

Smith, Smith, dan Verner (2006) dalam Sari dan Bahtiar (2014) memaparkan ada tiga alasan pentingnya memiliki direktur wanita pada dewan yaitu:

1. Anggota direksi wanita biasanya memiliki pemahaman yang lebih baik mengenai keadaan pasar dibandingkan dengan anggota direksi laki-laki.

2. Pemahaman ini akan meningkatkan keputusan yang lebih baik yang dibuat oleh dewan.

3. Anggota direksi wanita akan membawa gambaran yang lebih baik dalam persepsi masyarakat bagi perusahaan dan ini akan memberikan kontribusi positif terhadap kinerja perusahaan. 
4. Anggota dewan lainnya akan memiliki pemahaman yang disempurnakan dalam lingkungan bisnis saat perusahaan memiliki perwakilan dari anggota direksi wanita.

Berbagai penelitian menyebutkan bahwa adanya pengaruh positif diversitas gender dewan direksi terhadap kinerja keuangan perusahaan. Penelitian yang dilakukan oleh Erhadt (2003) dalam Kartikarini dan Siti (2012) menemukan diversitas dewan direksi berpengaruh positif dengan indikator keuangan pada kinerja perusahaan. Selain itu, penelitian yang dilakukan oleh Ramadhani dan Desi (2015) menunjukkan bahwa terdapat pengaruh positif diversitas gender dewan direksi terhadap kinerja keuangan perusahaan.

\section{Kepemilikan Institusional}

Struktur kepemilikan dapat disebut juga struktur kepemilikan saham, yaitu proporsi kepemilikan manajemen atau kepemilikan suatu instusi luar negeri, dalam negeri maupun pemerintah dalam kepemilikan saham perusahaan. Kepemilikan institusional umumnya dapat bertindak sebagai pihak yang memonitor perusahaan.Bushee (1998) dalam Fauzan, Nadirsyah, dan Muhammad (2012) mengemukakan bahwa kepemilikan institusional memiliki kemampuan untuk mengurangi insentif para manajer yang mementingkan diri sendiri melalui tingkat pengawasan yang intens. Menurut Faizal dalam Putra Surya (2013) perusahaan dengan kepemilikan institusional yang besar mengindikasikan kemampuannya untuk memonitor manajemen. Semakin besar kepemilikan institusional maka semakin efisien pemanfaatan aktiva perusahaan dan diharapkan juga dapat bertindak sebagai pencegahan terhadap pemborosan yang dilakukan oleh manajemen.

Dari beberapa peneliti, kepemilikan institusional dipercaya dapat mempengaruhi jalannya perusahaan yang pada akhirnya berpengaruh terhadap kinerja perusahaan. Penelitian yang dilakukan oleh Fauzan, Nadirsyah, dan Muhammad (2012) dan Waskito (2014) menemukan adanya pengaruh positif antara struktur kepemilikan institusional terhadap kinerja keuangan perusahaan.

\section{Ukuran Perusahaan}

Ukuran perusahaan merupakan salah satu variabel penting dalam pengelolaan perusahaan. Ukuran perusahaan mencerminkan seberapa besar penjualan yan diperoleh perusahaan.Penjualanmerupakan kegiatan utama suatu perusahaan yang memiliki pengaruh strategis terhadap perusahaan dan berkaitan dengan kompetisi dalam industri. Agar dapat melakukan penjualan perusahaan membutuhkan aktiva perusahaan.Peningkatan penjualan harus diikuti dengan peningkatan aktiva perusahaan (Weston dan Brigham, 1998 dalam Putra Surya, 2013).

Angka penjualan yang tinggi mempengaruhi keuntungan yang diperoleh perusahaan. Semakin tinggi perusahaan semakin tinggi pula laba yang dihasilkan. Perusahaan besar cenderung mendapat perhatian lebih dari masyarakat luas. Dengan demikian, biasanya perusahaan besar memiliki kecenderungan untuk selalu menjaga stabilitas dan kondisi perusahaan. Untuk menjaga stabilitas dan kondisi ini, perusahaan tentu saja akan berusaha mempertahankan dan terus meningkatkan kinerjanya. 
Penelitian yang dilakukan oleh Putra Surya (2013) dan Theacini dan I Gede (2015) menemukan adanya pengaruh positif ukuran perusahaan terhadap kinerja keuangan perusahaan.

\section{Hipotesis Penelitian}

Dari uraian teori dan variabel yang digunakan dalam penelitian ini, adapun hipotesis dalam penelitian ini adalah sebagai berikut:

$\mathrm{H}_{1}$ : Terdapat pengaruh positif diversitas gender dewan komisaris terhadap kinerja keuangan perusahaan.

$\mathrm{H}_{2}$ : Terdapat pengaruh positif diversitas gender dewan direksi terhadap kinerja keuangan perusahaan.

$\mathrm{H}_{3}$ : Terdapat pengaruh positif kepemilikian institusional terhadap kinerja keuangan perusahaan.

$\mathrm{H}_{4}$ : Terdapat pengaruh positif ukuran perusahaan terhadap kinerja keuangan perusahaan.

\section{METODE PENELITIAN}

Jenis penelitian yang digunakan dalam penelitian ini adalah penelitian asosiatif-kausal. Populasi dalam penelitian ini adalah perusahaan yang terdaftar di Bursa Efek Indonesia (BEI) pada tahun 2014 dan tahun 2015. Dalam penelitian ini sampel yang digunakan adalah perusahaan manufaktur yang terdaftar menjadi emiten di BEI (Bursa Efek Indonesia). Teknik pengambilan sampel menggunakan purposive sampling.

Kriteria-kriteria yang digunakan dalam penentuan sampel dalam penelitian ini adalah sebagai berikut:

1. Perusahaan tergolong dalam perusahaan manufaktur yang terdaftar di Bursa Efek Indonesia (BEI) pada tahun 2014 dan 2015.

2. Perusahaan menerbitkan laporan tahunan (annual report) pada tahun 2014 dan 2015.

3. Memiliki data yang lengkap terkait dengan variabel-variabel yang dibutuhkan.

4. Melaporkan laporan keuangan dalam mata uang rupiah.

5. Perusahaan memiliki nilai ROA yang positif pada tahun 2014 dan 2015 .

Jenis data yang digunakan dalam penelitian ini adalah data sekunder berupa data laporan tahunan serta laporan keuangan yang terdapat di Bursa efek Indonesia melalui situs www.idx.co.id. Data yang diperlukan adalah data untuk variabel ROA, diversitas gender dewan komisaris, diversitas gender dewan direksi, struktur kepemilikan institusional, dan ukuran perusahaan.

\section{Variabel Dependen Return on Asset (ROA)}

Dalam penelitian ini, variabel dependennya adalah kinerja keuangan perusahaan. Kinerja keuangan dapat menjadi patokan keberhasilan atau tidak pelaksanaan dari good corporate governance. Berdasarkan penelitian yang dilakukan oleh Ramadhani dan Desi (2015) kinerja keuangan dapat diukur menggunakan rasio ROA. 


$$
\mathrm{ROA}=\frac{\text { Laba Bersih }}{\text { Total Aset }}
$$

Nilai ROA yang semakin besar dapat memperkecil kemungkinan perusahaan melakukan manajemen laba. Hal ini didorong oleh tata kelola perusahaan yang semakin baik, sehingga dengan semakin kecilnya perilaku manajemen laba, maka kualitas laba perusahaan juga semakin baik serta semakin baik pula posisi perusahaan tersebut dari segi penggunaan aset.

\section{Diversitas Gender Dewan Komisaris}

Jackling dan Johl (2009) dalam Carter et al (2010) menemukan hubungan positif antara anggota dewan dan kinerja keuangan. Hubungan positifnya adalah anggota dewan akan memberikan informasi yang lebih baik karena pengetahuan yang lebih besar dari anggota dewan untuk mengambil keputusan yang terbaik bagi perusahaan. Perusahaan yang besar lebih mungkin memiliki anggota dewan wanita yang lebih banyak.

Diversitas gender diproksi dengan keberadaan wanita dalam jajaran dewan komisaris. Keberadaan wanita dalam jajaran dewan komisaris dihitung dengan dummy, dimana apabila terdapat anggota wanita dalam dewan komisaris akan diberi nilai 1, jika tidak diberi nilai 0 . Pengukuran ini mengacu pada penelitian Basundari dan I Komang (2013), Hanani dan Y Anni (2011), dan Ramadhani dan Desi (2015).

\section{Diversitas Gender Dewan Direksi}

Menurut WHO, gender didefinisikan sebagai perbedaan status dan peran antara pria dan wanita yang dibentuk oleh masyarakat sesuai dengan nilai budaya yang berlaku dalam periode tertentu. Diversitas dalam dewan direksi mengarah pada pengetahuan, kreativitas, dan inovasi yang selanjutnya menjadi keunggulan kompetitif. Keragaman gender direksi dapat memperkaya perspektif dalam pengambilan keputusan.

Diversitas gender diproksi dengan keberadaan wanita dalam jajaran dewan direksi. Keberadaan wanita dalam jajaran dewan direksi dihitung dengan dummy, dimana apabila terdapat anggota wanita dalam dewan komisaris akan diberi nilai 1, jika tidak diberi nilai 0. Pengukuran ini mengacu pada penelitian Basundari dan I Komang (2013), Hanani dan Y Anni (2011), dan Ramadhani dan Desi (2015).

\section{Struktur kepemilikan}

Strukur kepemilikan dibagi menjadi dua bagian yaitu kepemilikan manajerial dan kepemilikan institusional. Kepemilikan manajerial adalah situasi dimana manajer perusahaan memiliki saham perusahaan itu sendiri atau dengan kata lain manajer tersebut sekaligus sebagai pemegang saham perusahaan. Sedangkan kepemilikan institusional merupakan proporsi kepemilikan saham oleh institusi seperti perusahaan asuransi, bank, pemerintah, institusi asing dan perusahaan-perusahaan investasi lainnya. 


$$
\text { Kepemilikan Institusional }=\frac{\text { Jumlah Saham Institusional }}{\text { Total Saham Beredar }} \times 100 \%
$$

\section{Ukuran Perusahaan}

Menurut Sha (2014) ukuran perusahaan adalah mengukur besar atau kecilnya lingkup perusahaan dalam melakukan kegiatan operasi.Ukuran perusahaan dalam penelitian ini dihitung menggunakan Ln Total Asset.

$$
\text { Ukuran Perusahaan }=\text { Ln Total Asset }
$$

\section{Pengujian Hipotesis}

Uji $\mathrm{T}$ adalah jenis pengujian statistika untuk mengetahui apakah ada perbedaan dari nilai yang diperkirakan dengan nilai hasil perhitungan statistika. Pengujian hipotesis dalam penelitian ini menggunakan uji signifikansi parameter individual disebut juga uji statistik t. Pengujian ini untuk menunjukkan seberapa jauh pengaruh satu variabel independen secara invididual dalam menerangkan variasi variabel bebas. Model Penelitian dapat dilihat pada Gambar 1 sebagai berikut;

\section{Gambar 1 Model Penelitian}

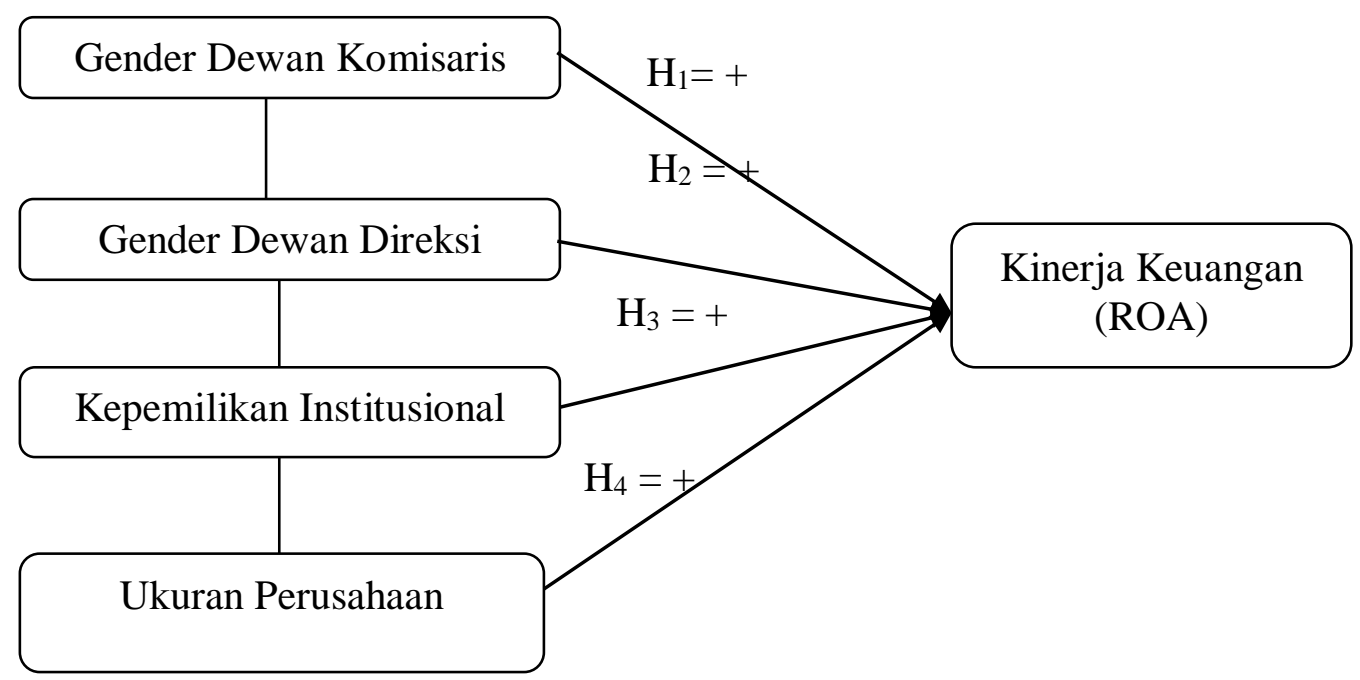

\section{HASIL DAN PEMBAHASAN}

\section{Statistik Deskriptif}

Nilai ROA pada perusahaan sampel memiliki rata-rata sebesar 0,049. Return on Asset (ROA) adalah salah satu bentuk dari rasio profitabilitas untuk mengukur kemampuan perusahaan dalam menghasilkan laba dengan menggunakan total aktiva yang ada dan setelah biaya-biaya modal (biaya yang digunakan mendanai aktiva) dikeluarkan dari analisis. Nilai ROA yang positif menunjukan bahwa dari total aktiva yang dipergunakan untuk operasi perusahaan mampu memberikan laba bagi perusahaan. Jadi jika suatu perusahaan mempunyai 
ROA yang tinggi maka perusahaan tersebut berpeluang besar dalam meningkatkan pertumbuhan.

\section{Tabel 1}

Hasil Statistik Deskriptif Penelitian

\begin{tabular}{lccc}
\hline & Minimum & Maximum & Mean \\
\hline ROA & $-0,09$ & 0,32 & 0,052 \\
\hline Komisaris & 0,38 & 1 & 0,22 \\
\hline Direksi & 0,38 & 1 & 0,23 \\
\hline K_Institusional & 0,10 & 0,79 & 0,45 \\
\hline Size & 12,68 & 22,26 & 17,48
\end{tabular}

Sumber: data sekunder yang diolah dengan software SPSS versi 20

Nilai dari variabel dewan komisaris dan dewan direksi menghasilkan nilai rata-rata sebesar 0,22 dan 0,23 . Hal ini berarti persentase peran wanita dalam jajaran dewan komisaris dan dewan direksi dalam perusahaan sampel sebesar 22\% dan $23 \%$. Nilai rata-rata dewan komisaris turun $12 \%$ dan dewan direksi naik $11 \%$ dari data pada tahun 2012, yaitu 34\%. Menurunnya persentase peran wanita dalam sebuah perusahaan menandakan adanya ketidakpercayaannya perusahaan terhadap kemampuan wanita dalam memimpin perusahaan. Kemampuan wanita dalam memimpin perusahaan masih dinilai rendah. Hasil ini berbeda jauh dengan peraturan negara Norwegia yang mengharuskan peran wanita dalam perusahaan di negaranya sebesar $40 \%$. Dengan menurunnya persentase kepemimpinan wanita dalam sebuah perusahaan menandakan bahwa di Indonesia pemimpin perusahaan masih didominasi oleh peran laki-laki.

Kepemilikan institusional memiliki rata-rata nilai sebesar 0,45. Hal ini menandakan bahwa sebesar $45 \%$ saham perusahaan sampel dimiliki oleh sebuah instansi misalnya perusahaan asing maupun domestik, pemerintah dan instansi lainnya. Kepemilikan institusional merupakan kepemilikan investasi terbesar. Semakin besar nilai kepemilikan institusional, semakin besar pula tekanan yang diterima manajemen purusahaan untuk meningkatkan kinerja keuangan perusahaan. Tingginya nilai kepemilikan institusional membuktikan kinerja keuangan perusahaan baik. Hal ini membuktikan bahwa investor institusional dapat mengendalikan manajemen perusahaan untuk mengembangkan perusahaan.

Nilai rata-rata yang dimiliki variabel ukuran perusahaan adalah 17,48. Hal ini berarti perusahaan sampel memiliki total aset sekitar $17 \%$. Ukuran perusahaan sampel dapat dikatakan kecil, karena nilai maksimum yang dimiliki variabel ukuran perusahaan sebesar $22 \%$, dilihat dari total aset yang dimiliki oleh perusahaan tersebut. Nilai ini kurang dari 50\%. Bukan berarti perusahaan yang memiliki total aset kecil tidak memiliki kinerja perusahaan yang buruk pula. 


\section{Hasil Persamaan Regresi}

Hasil pengujian regresi linear berganda dalam penelitian ini adalah:

$$
\mathrm{Y}=-0,110-0,008 \mathrm{X}_{1}-0,007 \mathrm{X}_{2}+0,107 \mathrm{X}_{3}+0,007 \mathrm{X}_{4}+\mathrm{e}
$$

\section{Koefisien Determinasi $\left(\mathbf{R}^{2}\right)$}

Nilai Adjusted $\mathrm{R}$ Square $\left(\mathrm{R}^{2}\right)$ sebesar 0,025 menunjukkan bahwa variasi dari kinerja keuangan dapat dijelaskan oleh variabel gender dewan komisaris, gender dewan direksi, kepemilikan institusional, dan ukuran perusahaan sebesar $2 \%$. Sedangkan sisanya di jelaskan $98 \%$ dipengaruhi oleh faktor-faktor lain di luar dari variabel dalam penelitian ini.

\section{Hasil Pengujian Hipotesis}

Tabel 2

Hasil Uji T Regresi Linear Berganda

\begin{tabular}{clccc}
\hline Hipotesis & \multicolumn{1}{c}{ Variabel } & $\mathrm{t}$ & Sig. & Kesimpulan \\
& & $-0,545$ & 0,587 & $\mathrm{H}_{1}$, ditolak \\
\hline 1 & Dewan Komisaris & $-0,493$ & 0,263 & $\mathrm{H}_{2}$, ditolak \\
\hline 2 & Dewan Direksi & 2,484 & 0,014 & $\mathrm{H}_{3}$, diterima \\
\hline 3 & Kepemilikan Institusional & & & \\
\hline 4 & Ukuran Perusahaan & 1,485 & 0,140 & $\mathrm{H}_{4}$, ditolak
\end{tabular}

Sumber: data diolah

Hasil pengujian hipotesis pertama $\left(\mathrm{H}_{1}\right)$ menunjukkan nilai sig. 0,587 . Hasil ini lebih besar 0.05. Oleh karena itu dapat disimpulkan bahwa diversitas dewan komisaris tidak berpengaruh secara positif terhadap kinerja keuangan perusahaan. Hasil pengujian hipotesis kedua $\left(\mathrm{H}_{2}\right)$ menunjukkan nilai sig. 0,263 . Hasil ini lebih besar dari 0.05. Oleh karena itu dapat disimpulkan bahwa diversitas dewan direksi tidak berpengaruh secara positif terhadap kinerja keuangan perusahaan. Hasil pengujian hipotesis ketiga $\left(\mathrm{H}_{3}\right)$ menunjukkan nilai sig. 0,014. Hasil ini lebih kecil dari 0.05. Oleh karena itu dapat disimpulkan bahwa struktur kepemilikan institusional berpengaruh secara positif terhadap kinerja keuangan perusahaan. Dalam penelitian ini untuk variabel kepemilikan institusional $\mathrm{H}_{0}$ ditolak dan $\mathrm{H}_{\mathrm{a}}$ diterima. Hasil pengujian hipotesis keempat $\left(\mathrm{H}_{1}\right)$ menunjukkan nilai sig. 0,140. Hasil ini lebih besar dari 0.05. Oleh karena itu dapat disimpulkan bahwa ukuran perusahaan tidak berpengaruh secara positif terhadap kinerja keuangan perusahaan. Nilai dari $t$ hitung lebih besar dari $t$ tabel yaitu 2,582 > 1,65714.Untuk hipotesis yang diterima, nilai t hitung harus lebih besar dari nilai t tabel. Dalam penelitian ini untuk variabel ukuran perusahaan $\mathrm{H}_{0}$ diterima.

\section{Diversitas Gender Dewan Komisaris dan Pengaruhnya terhadap Kinerja Keuangan.}

Hasil penelitian menunjukkan bahwa diversitas dewan komisaris berpengaruh negatif terhadap kinerja keuangan yang diproksi dengan rasio ROA. 
Deaux dan Ernswiller dalam Hanani dan Y. Anni (2011) berpendapat bahwa penyebab kesuksesan kepemimpinan laki-laki adalah faktor kemampuan yang tinggi, sedangkan kesuksesan kepemimpinan wanita hanya karena faktor keberuntungan saja. Keberadaan wanita dalam anggota dewan komisaris masih dianggap rendah dan tidak mampu memimpin perusahaan. Hasil penelitian ini sejalan dengan penelitian yang dilakukan oleh Hanani dan Y. Anni (2011) yang menyatakan tidak ada pengaruh positif diversitas dewan komisaris terhadap kinerja keuangan. Hasil penelitian ini tidak sejalan dengan penelitian yang dilakukan oleh Ramadhani dan Desi (2015) yang menyatakan bahwa keberadaan wanita dalam dewan komisaris berpengaruh positif terhadap kinerja keuangan.

\section{Diversitas Gender Dewan Direksi dan Pengaruhnya terhadap Kinerja Keuangan}

Hasil penelitian hipotesis kedua $\left(\mathrm{H}_{2}\right)$ memiliki nilai sig. 0,263 yang memiliki nilai yang lebih besar dari 0,05. Hasil penelitian ini juga mendukung hasil penelitian yang dilakukan oleh Hanani dan Y. Anni (2011).Diduga karena wanita kurang menyukai resiko daripada pria dalam mengambil sebuah keputusan, sehingga wanita memiliki presentase yang lebih kecil daripada pria dalam menduduki jabatan di sebuah perusahaan.

Tetapi hasil penelitian ini tidak sesuai dengan penelitian yang dilakukan oleh Carter, et al (2010) yang membuktikan bahwa keberadaan wanita dalam dewan direksi akan menghasilkan kinerja yang lebih baik, karena keputusan yang dihasilkan oleh dewan koisaris maupun dewan direksi merupakan usaha untuk mencapai kinerja yang maksimal.

\section{Struktur Kepemilikan Institusional dan Pengaruhnya terhadap Kinerja Keuangan}

Variabel independen kepemilikan institusional berpengaruh terhadap kinerja keuangan pada tingkat signifikan 0,05 , sehingga hipotesis $\mathrm{H}_{3}$ diterima. Nilai signifikan dari kepemilikan adalah $0,014<0,05$. Hasil penelitian ini sejalan dengan penelitian yang dilakukan oleh Fauzan, Nadirsyah, dan Muhammad (2012) dan waskito (2014) menunjukkan bahwa kepemilikan institusional berpengaruh positif terhadap hubungan kinerja keuangan perusahaan. Semakin tinggi modal dari investor institusional semakin bagus pula kinerja keuangan perusahaan. Karena pihak manajemen perusahaan di tuntut untuk memberikan hasil yang terbaik di akhir periode yaitu dapat menghasilkan laba semaksimal mungkin. Selain dikontrak untuk meingkatkan kinerja keuangan perusahaan, manajemen juga dikontrak untuk meingkatkan kesejahteraan investor institusional dengan meningkatkan laba.

Kepemilikan institusional merupakan kepemilikan saham oleh pihak institusi lain. Kepemilikan institusional merupakan salah satu alat yang dapat mengurangi agency conflict. Kepemilikan institusional memiliki kemampuan untuk mengendalikan pihak manajemen melalui proses monitoring secara efektif sehingga dapat mengurangi manajemen laba yang bisa dilakukan oleh pihak manajemen perusahaan (Gideon, 2005 dalam Waskito, 2014). Hasil penelitian ini tidak sejalan dengan penelitian yang dilakukan oleh Wehdawati, Fifi, dan Sufi 
(2015) yang menunjukkan bahwa struktur kepemilikian institusional tidak berpengaruh terhadap kinerja keuangan perusahaan.

\section{Ukuran Perusahaan dan Pengaruhnya terhadap Kinerja Keuangan}

Variabel ukuran perusahaan memiliki nilai sig. 0,140. Artinya hipotesis $\mathrm{H}_{4}$ ditolak, ukuran perusahaan mempunyai pengaruh negatif terhadap kinerja keuangan. Semakin besar ukuran perusahaan, semakin rendah kinerja keuangannya. Hal ini disebabkan karena semakin besar ukuran perusahaan belum tentu penggunaan dari aset dimanfaatkan sebaik mungkin oleh pihak manajemen.

Penelitian ini tidak sejalan dengan penelitian yang dilakukan oleh Theacini dan I Gede (2014) menemukan bahwa adanya pengaruh yang signifikan ukuran perusahaan terhadap kinerja keuangan perusahaan. Hasil penelitian ini sejalan dengan penelitian yang dilakukan oleh Isbanah (2015) dan Mahaputeri dan I. Kt. Yadnyana (2014) yang menemukan bahwa ukuran perusahaan berpengaruh negatif terhadap kinerja keuangan perusahaan.

\section{KESIMPULAN DAN IMPLIKASI}

\section{Kesimpulan}

Penelitian ini bertujuan untuk menguji pengaruh diversitas gender, kepemilikan institusional, dan ukuran perusahaan terhadap kinerja keuangan perusahaan. Hasil penelitian ini menunjukkan bahwa:

1. Diversitas gender dewan komisaris tidak berpengaruh positif terhadap kinerja keuangan. Hal ini disebabkan karena wanita masih dianggap rendah untuk memimpin sebuah perusahaan. Faktor keberuntungan atau keluarga yang dapat menjadikan wanita sebagai anggota dewan dalam perusahaan.

2. Gender dewan direksi tidak berpengaruh positif terhadap kinerja keuangan. Hal ini disebabkan karena wanita tidak menyukai resiko yang besar dalam mengambil keputusan dibandingkan dengan laki-laki. Sehingga tidak dapat meningkatkan kinerja keuangan perusahaan.

3. Sedangkan untuk variabel kepemilikan institusional secara signifikan berpengaruh positif terhadap kinerja keuangan.Semakin besar kepemilikan institusional semakin bagus kinerja manajemen karena pihak manajemen dituntut untuk memberikan yang terbaik bagi perusahaan dan investor.

4. Ukuran perusahaan berpengaruh negatif terhadap kinerja keuangan. Hal ini membuktikan semakin besar ukuran perusahaan semakin rendah kinerja keuangan perusahaan karena perusahaan tidak dapat memanfaatkan total aset yang dimiliki perusahaan untuk meningkatkan kinerja keuangan. Selain itu, perusahaan tidak didukung pengolah aset dengan baik. Sehingga tidak dapat meningkatkan kinerja keuangan perusahaan.

\section{Keterbatasan dan Saran}

Penelitian ini memiliki beberapa keterbatasan, yaitu:

1. Data dalam penelitian ini menggunakan data sekunder, yaitu data gender dewan komisaris dan dewan direksi hanya terpaku pada data yang disediakan di IDX, peneliti tidak bertanya langsung kepada pemimpin perusahaan. 
2. Periode penelitian relatif singkat (hanya menggunakan dua tahun periode observasi).

3. Sampel yang digunakan hanya perusahaan manufaktur saja.

4. Variabel yang digunakan dalam penelitian ini hanya empat variabel yaitu gender dewan komisaris, gender dewan direksi, kepemilikan institusional, dan ukuran perusahaan.

Dari beberapa keterbatasan tersebut, peneliti memiliki beberapa saran bagi peneliti selanjutnya. Peneliti selanjutnya diharapkan:

1. Dapat mengganti jenis data yang digunakan. Misalnya saja bertanya langsung kepada perusahaan yang pemimpinnya laki-laki, apakah peran wanita dalam memimpin perusahaan tidak diperlukan untuk meingkatkan kinerja perusahaan.

2. Dapat menambah periode pengamatan yang tidak hanya dua tahun saja tetapi bisa tiga sampai lima tahun.

3. Sampel yang digunakan diharapkan dapat diperluas bukan hanya perusahaan manufaktur saja, melainkan seluruh perusahaan yang terdaftar di BEI.

4. Terakhir, peneliti selanjutnya diharapkan dapat menambah variabel penelitian yang dapat kiranya dapat mempengaruhi kinerja keuangan.

\section{DAFTAR PUSTAKA}

Basundari, Ida Ayu Putu Suabdi dan I Komang Arthana.2013. Pengaruh Diversitas Gender dan Kebangsaan pada Corporate Governance Disclosure Perusahaan Perbankan di Bursa Efek Indonesia. Jurnal Riset Akuntansi (JUARA). Vol. 3, No. 2.

Carter, David A, Frank D’Souza, Betty J Simkins, and W. Eary Simpson. 2010. The Gender and Ethnic Diversity of US Boards And Board Committees and Firm Financial Performance. Corporate Governance : An International Review 18 (5): 396-414.

Dunia News Viva.co.id.Lebih Banyak Komisaris Perempuan, Perusahaan Hasilkan Lebih Banyak Uang. Diakses tanggal 10 Maret 2016.

Fauzan, Faisal, Nadirsyah, dan Muhammad Arfan. 2012. Pengaruh Struktur Kepemilikan dan Kinerja Keuangan Early Warning System terhadap Nilai Perusahaan (Studi pada Perusahaan Asuransi yang Terdaftar di Bursa Efek Indonesia). Jurnal Akuntansi. Vol. 2, No. 1, Hal.64-75.

Fachrudin, Khaira Amalia. 2011. Analisis Pengaruh Struktur Modal, Ukuran Perusahaan, dan Agency Cost terhadap Kinerja Perusahaan. Jurnal Akuntansi dan Keuangan.Vol. 13, No. 1, Hal.37-46.

Ghozali, Imam. 2013. Aplikasi Analisis Multivariate dengan Program IBM SPSS 21. Badan Penerbit Universitas Diponegoro. Semarang

Hanani, Famera dan Y Anni Aryani. 2011. Pengaruh Gender Dewan Komisaris, Gender Dewan direksi, dan Kepemilkan Manajerial Terhadap Kinerja Perusahaan. Wahana.Vol. 14, No.1.

Isbanah, Yuyun. 2015. Pengaruh ESOP, Leverage, and Ukuran Perusahaan Terhadap Kinerja Keuangan Perusahaan di Bursa Efek 
Indonesia.JOURNAL of RESEARCH in ECONOMICS and MANAGEMENT (Jurnal Riset Ekonomi dan Manajemen).Vol. 15, No.1, Hal.28-41.

Jogiyanto.2007. Metodologi Penelitian Bisnis Salah Kaprah dan PengalamanPengalaman.BPFE-Yogyakarta. Yogyakarta

Kartikarini, Nurrahmah dan Siti Mutmainah. 2013. Analisis Pengaruh Diversitas Gender Terhadap Voluntary Corporate Governance Disclosure dalam Laporan Tahunan Perusahaan. Diponegoro Journal Of Accounting. Vol. 2, No. 1.

Putra, I Komang Dedy Adnyana dan Ni Gusti Putu Wirawati.2013. Pengaruh Kepemilikan Manajerial Terhadap Hubungan Antara Kinerja dengan Nilai Perusahaan.E-Jurnal Akuntansi.Vol. 5, No. 3, Hal.639-651.

Ramadhani, Zhafarina dan Desi Ahdariani. 2015. Pengaruh Keberagaman Gender Terhadap Kinerja Keuangan Perusahaan dan Efisiensi Investasi. Simposium Nasional Akuntansi 18, Medan, 16-19 September 2015.

Sari, Derry Permata dan Bahtiar Usman. 2014. Pengaruh Board Structure dan Ownership Structure Terhadap Firm Performance pada Perusahaan Manufaktur yang Terdaftar di Bursa Efek Indonesia. E-Jurnal Manajemen.Vol. 1, No. 2, Hal.44-69.

Sha, Thio Lie. 2014. Pengaruh Ukuran Perusahaan, Ukuran Dewan Komisaris, Profitabilitas dan Leverage terhadap Pengungkapan Tanggung Jawab Sosial pada Perusahaan Manufaktur yang Terdaftar di BEI. Jurnal Akuntansi. Vol. XVIII, No. 1, Hal. 86-98.

Sirait, Justine T. 2007. Manajemen Sumber Daya Manusia dalam Organisasi Internasional.Mitra Wacana Media. Jakarta.

Sudiartana, I Made. 2013. Pengaruh Diversitas Gender dan Latar Belakang Pendidikan Dewan direksi Terhadap Luas Pengungkapan Sukarela. Jurnal Riset Akuntansi (JUARA). Vol. 3, No. 2.

Sugiarto, Melanie. 2011. Pengaruh Struktur Kepemilikan dan Kebijakan Deviden terhadap Nilai Perusahaan dengan Kebijakan Hutang sebagai Intervening. Jurnal Akuntansi Kontemporer. Vol. 3, No. 1, Hal.1-25.

Surya, Indra dan Ivan Yustiavandana. 2008. Penerapan Good Corporate Governance: Mengesampingkan Hak-Hak Istimewa Demi Kelangsungan Usaha. Prenada Media Group. Jakarta.

Theacini, Deby Anastasia Meilic dan I GedeSuparta Wisadha. 2014. Pengaruh Good Corporate Governance, Kualitas Laba, dan Ukuran Perusahaan pada Kinerja Perusahaan. E-Jurnal Akuntansi.Vol. 7, No. 3, Hal.733-746.

Waskito, Titis. 2014. Pengaruh Struktur Kepemilikan Manajerial, Kepemilikan Institusional, dan Ukuran Perusahaan terhadap Kinerja Keuangan (Ditinjau dari Perusahaan Manufaktur yang Terdaftar di Bursa Efek Indonesia Tahun 2008 - Tahun 2011).Fakultas Ekonomi dan Bisnis.Universitas Muhammadiyah Surakarta.

Wahana Komputer. 2012. Solusi Praktis dan Mudah Menguasai SPSS 20 untuk Pengolahan Data. Andi Offset. Yogyakarta

Wehdawati, Fifi Swandari, Sufi Jikrillah. 2015. Pengaruh Mekanisme Good Corporate Governance dan Struktur Kepemilikan terhadap Kinerja 
Keuangan Perusahaan Manufaktur yang Terdaftar di BEI Tahun 20102012. Jurnal Wawasan Manajemen. Vol. 3, No. 3.

\section{LAMPIRAN}

Hasil Pengujian Normalitas Sebelum Outlier

\begin{tabular}{cc}
\hline Keterangan & $\begin{array}{c}\text { Unstandardized } \\
\text { Residual }\end{array}$ \\
\hline $\mathrm{N}$ & 130 \\
\hline Kolmogorov-Smirnov Z & 1,418 \\
\hline Asymp. Sig. (2-tailed) & 0,036
\end{tabular}

Sumber: data sekunder yang diolah dengan software SPSS versi 20

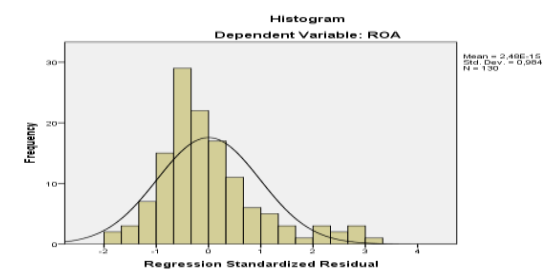

Histogram Pengujian Normalitas

Hasil pengujian Normalitas setelah Transformasi

\begin{tabular}{cc}
\hline Keterangan & $\begin{array}{c}\text { Unstandardized } \\
\text { Residual }\end{array}$ \\
\hline $\mathrm{N}$ & 130 \\
\hline Kolmogorov-Smirnov Z & 3,847 \\
\hline Asymp. Sig. (2-tailed) & 0,000
\end{tabular}

Sumber: data diolah 
Hasil Pengujian Normalitas setelah Timing

Keterangan Unstandardized Residual

\begin{tabular}{lc}
\hline \multicolumn{1}{c}{$\mathrm{N}$} & 125 \\
\hline Kolmogorov-Smirnov Z & 1,297 \\
\hline Asymp. Sig. (2-tailed) & 0,069
\end{tabular}

Sumber: data diolah

\section{Uji Heteroskedastisitas}

Hasil Pengujian Asumsi Heteroskedastistas

\begin{tabular}{lc}
\hline \multicolumn{1}{c}{ Variabel } & Sig. \\
\hline D_Komisaris & 0,903 \\
\hline D_Direksi & 0,299 \\
\hline K_Institusional & 0,090 \\
\hline Size & 0,824 \\
\hline
\end{tabular}

Sumber: data diolah

Uji Multikolinearitas

\begin{tabular}{lcc}
\hline \multirow{2}{*}{ Variabel } & \multicolumn{2}{c}{ Collinearity Statistics } \\
\cline { 2 - 3 } & Tolerance & VIF \\
\hline Komisaris & 0,939 & 1,065 \\
\hline Direksi & 0,983 & 1,017 \\
\hline K_Institusional & 0,911 & 1,098 \\
\hline Size & 0,865 & 1,156 \\
\hline
\end{tabular}

Sumber: data diolah 
